\title{
PROGRAM PELATIHAN PERLINDUNGAN RESIKO KEBAKARAN DENGAN PENGENALAN DAN PENGGUNAAN APAR
}

\author{
Prasetya Sigit Santosa, Ningrum Astriawati*, Wegig Pratama, Waris Wibowo, \\ Benny Hartanto \\ Program Studi Permesinan Kapal, Sekolah Tinggi Maritim Yogyakarta, \\ Jl. Magelang KM 4.4, Kutu Dukuh, Sinduadi, Kec. Mlati, Kabupaten Sleman \\ Daerah Istimewa Yogyakarta \\ *Email: astriamath@gmail.com
}

\begin{abstract}
Abstrak
Kebakaran yang terjadi di Yogyakarta mengalami peningkatan dari tahun sebelumnya naik ke tahun berikutnya, khususnya di daerah yang padat penduduknya serta pada wilayah atau daerah industri. Kebakaran merupakan hal yang sering terjadi, dan ini akan membahayakan serta mengancam keselamatan jiwa seseorang. Oleh karena itu sangat dibutuhkan sikap kesadaran serta kesiapan untuk menangani apabila terjadi kebakaran dan ini perlu peran serta dukungan baik oleh masyarakat itu sendiri maupun pemerintah setempat. Bertolak dari sering terjadinya bencana kebakaran tersebut sangat diperlukan suatu pelatihan perlindungan risiko kebakaran dengan pengenalan dan penggunaan APAR. Pelatihan yang dilakukan bertujuan agar masyarakat lebih mengetahui serta memahami bagaimana bila terjadi musibah kebakaran serta bagaimana penanggulangannya. Pelatihan dilakukan di Dusun Condong Catur, Depok, Sleman, Yogyakarta, karena wilayah ini sangat padat penduduknya dan riskan terjadi kebakaran, disamping itu dusun Condong Catur letaknya berdampingan dengan kota Yogyakarta yang penduduknya padat. Peserta berjumlah 30 orang. Dari hasil pelatihan terjadi peningkatan pemahaman sebelum dan sesudah pelatihan, diantaranya terjadi peningkatan pemahaman mengenai konsep segitiga api sebesar 90\%, peningkatan pemahaman pengetahuan penggunaan APAR sebesar $87 \%$, dan peningkatan konsep pemadaman tradisional mengalami peningkatan sebesar $83 \%$.
\end{abstract}

Kata kunci: APAR, Pelatihan, Kebakaran

\section{PENDAHULUAN}

Musibah kebakaran sering menimpa di Kota Yogyakarta, dan musibah kebakaran ini terjadi dari tahun ke tahun. Menurut sumber data dari BPS ditunjukkan bahwa dari tahun ke tahun musibah terjadinya kebakaran di wilayah Kota Yogyakarta (Badan Pusat Statistik, 2017). Hal ini diketahui bahwa terjadinya musibah kebakaran karena adanya kompor meledak, terjadi jaringan listrik rumah tangga yang korsleting dan lainnya. Permukiman yang padat penduduk di wilayah Kota Yogyakarta dan sekitarnya cenderung menjadi potensi terjadinya kebakaran yang semakin meningkat. Musibah kebakaran akan sering melanda di daerah Kawasan perkotaan (Ma'ruf, 2010). Hunian perkampungan yang padat penduduknya, serta letak bangunan rumah yang berdekatan dan keadaan jaringan listrik yang tidak diperhatikan akan mempercepat timbulnya musibah kebakarand di Yogyakarta dan sekitarnya (Sardiyo, 2010). Cakupan pelayanan kejadian musibah kebakaran di kota Yogyakarta mencapai 100 persen. Hal ini berdasar dari hitungan dengan cara membagi luas Wilayah Manajemen Kebakaran (WMK) dengan luasnya wilayah yang berpotensi menjadi ancaman terjadinya kebakaran daerah perkotaan. Luas wilayah kota Yogyakarta tercatat $32,5 \mathrm{~km}^{2}$ dan seluruhnya akan mengalami potensi kebakaran.

Tabel. 1 Layanan Cakupan Musibah Kebakaran di Kota Yogyakarta Tahun 2012 - 2016

\begin{tabular}{llllllll}
\hline No & Indikator & satuan & 2012 & 2013 & 2014 & 2015 & 2016 \\
\hline 1 & $\begin{array}{l}\text { Luasan Wilayah Manajemen } \\
\text { Kebakaran (WMK) }\end{array}$ & $\mathrm{Km}^{2}$ & 32,5 & 32,5 & 32,5 & 32,5 & 32,5 \\
2 & $\begin{array}{l}\text { Luasan wilayah berpotensi ancaman } \\
\text { kebakaran }\end{array}$ & $\mathrm{Km}^{2}$ & 32,5 & 32,5 & 32,5 & 32,5 & 32,5 \\
$\begin{array}{l}\text { Cakupan layanan musibah kebakaran } \\
\text { di wilayah Perkotaan }\end{array}$ & persen & 100 & 100 & 100 & 100 & 100 \\
\hline
\end{tabular}

Sumber: Dinas Kebakaran Wilayah Kota Yogyakara 2017 
Daerah perkotaan khususnya di Kota Yogyakarta berpotensi musibah kebakaran. Berdasar dari data tersebut yang dimulai tahun 2012 sampai tahun 2016 luas Wilayah Manajemen Kebakaran (WMK) 32,5 km² semuanya berpotensi bencana kebakaran. Oleh karena itu kawasan yang padat penduduk, kawasan toko, lingkungan pasar, tempat titik layanan publik, tempat yang umum maupun instalasi untuk kawasan jalan berpotensi akan terjadi bahaya kebakaran. Musibah kebakaran juga tidak bisa dihindari pada jalan yang dilalui oleh kendaran bermotor. Oleh sebab itu diperlukan peningkatan disiplin serta kesadaran masyarakat dalam berupaya guna pencegahan musibah kebakaran khususnya di rumah tangga. Dari data Dinas Kebakaran Kota Yogyakara 2017 diketahui bahwa dari tahun 2012 sampai 2016 musibah kebakaran selalu meningkat mulai tahun 2012 terjadi 50 kejadian kebakaran, tahun 2013 terjadi 51 kejadian kebakaran, tahun 2014 terjadi peningkatan sekitar 55 kejadian, tahun 2015 sedikit penurunan yaitu 49 kejadian kebakaran dan tahun 2016 terjadi 63 kasus kebakaran.

Kebakaran mengakibatkan lebih dari 300.000 kematian setiap tahunnya dan merupakan penyebab cedera dengan jumlah terbesar ke empat di seluruh dunia (setelah kecelakaan lalu lintas, terjatuh dan kasus tenggelam) (Heide, 2004). Kebakaran juga dapat membuat masyarakat trauma dari segi psikologi serta terkadang merenggut korban jiwa. Dari segi ekonomi dapat berdampak terhadap pendapatan masyarakat (Ghifary, 2014).

Kebakaran ini juga merupakan kriteria keadaan darurat di kawasan perusahaan serta masyarakat, baik yang berasal dari luar maupun dari dalam lokasi di tempat kerja. Musibah terjadinya kebakaran pada umumnya akan menimbulkan banyak kerugian yang dialami, selain jiwa manusia kerugian harta dan benda yang bergerak maupun tidak bergerak, hal tersebut juga bisa terjadi di lingkungan masyarakat pada umumnya. Sedangkan pada umumnya kejadian kebakaran akan sulit untuk dapat dikendalikan (dipadamkan). Untuk menjaga dan menghindari dari kerugian dalam musibah kebakaran, akan sangat diperlukan untuk mengenali sifat-sifat terjadinya (tahap-tahap) kebakaran dan peralatan pemadam api ringan yang dapat dipergukan oleh masyarakat.

Dengan adanya kecenderungan meningkatnya kejadian kebakaran tersebut, maka dukungan sarana dan prasarana kebakaran mutlak untuk dihadirkan oleh pemerintah setempat di berbagai lokasi pemukiman termasuk di pemukiman padat penduduk. Selain itu sebagai tindakan pencegahan dan kesiapsiagaan dalam menghadapi bencana khususnya bencana kebakaran, sangat perlu dilakukan intervensi berupa pelatihan penanggulangan risiko kebakaran dengan menggunakan Alat Pemadam Api Ringan (APAR) yang dilengkapi dengan praktik langsung, agar masyarakat dapat memahami dan memiliki soft skill dalam menanggulangi terjadinya peristiwa kebakaran.

\section{METODE}

Pelatihan penanggulangan risiko kebakaran dengan menggunakan Alat Pemadam Api Ringan (APAR) dilaksanakan di pemukiman warga yang beralamatkan di Condong Catur, Depok, Sleman, Yogyakarta sebagai sasaran dari sosialisasi ini berada di area permukiman yang penduduknya sangat padat serta berpotensi terjadi musibah kebakaran yang tinggi. Sosialisasi dihadiri oleh 30 warga setempat. Skema pelaksanaan pelatihan ditunjukkan pada gambar berikut:

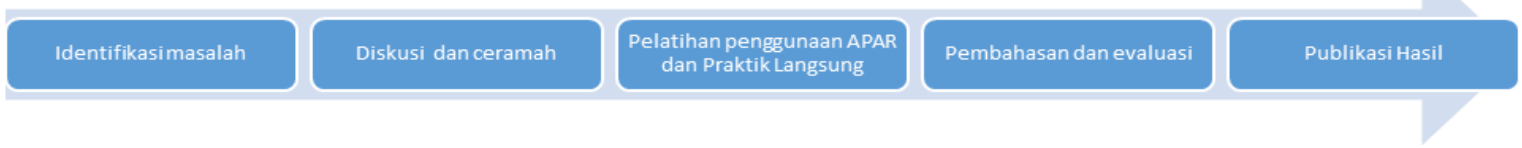

\section{Gambar 1. Skema Pelaksanaan Pelatihan}

Pelaksanaan pelatihan dilakukan dengan cara memberikan pemahaman masyarakat terhadap materi bila terjadi musibah kebakaran serta bagaimana cara menanggulanginya. Pelatihan dilaksanakan menggunakan cara dengan metode ceramah penyampaian materi serta dilanjutkan dengan diskusi peserta dan mudah dimengerti oleh masyarakat. Setelah itu diteruskan dengan metode praktik memberikan contoh memadamkan api, dilanjutkan oleh peserta untuk mematikan api dengan peralatan Alat Pemadam Api Ringan (APAR) atau tabung pemadam api maupun dengan kain, karung goni yang basah. Selanjutnya dilakukan evaluasi tentang pemahaman dari materi pelatihan yang telah diberikan dengan cara berdiskusi. 


\section{HASIL \& PEMBAHASAN}

Peralatan pemadam api ringan (APAR) merupakan peralatan yang ringan dan digunakan untuk memadamkan api apabila terjadi kebakaran(Kurniawan, Ekawati and Firdani, 2014). Permasalahan yang terjadi di sebagian peserta pelatihan adalah kurangnya pemahaman tentang penggunaan alat tersebut, disamping itu sebagaian besar juga kurang memahami penyebab kebakaran dan cara mengatasinya. Dari hasil berdasarkan evaluasi pelatihan yang dilakukan dengan pengelompokan indikator peserta pelatihan yang dapat memahami atau mengerti materi sosialisasi pelatihan. Indikator dari pemahaman yang dapat dicapai oleh peserta pelatihan: (1) Peserta pelatihan memahami bagaimana penyebab dari kebakaran melalui konsep materi Segitiga Api, (2) Peserta pelatihan mengerti dalam memadamkan api dengan cara tradisional memanfaatkan kain/serat dari goni yang basah, (3) Peserta pelatihan mengerti tentang mematikan api menggunakan Alat Pemadam Api Ringan (APAR).

Berdasarkan dari kriteria di atas akan dapat diperoleh data tentang pemahaman sebelum dan sesudah disampaiakan tentang materi sosialisasi yang dapat dilihat pada Gambar 2 berikut.

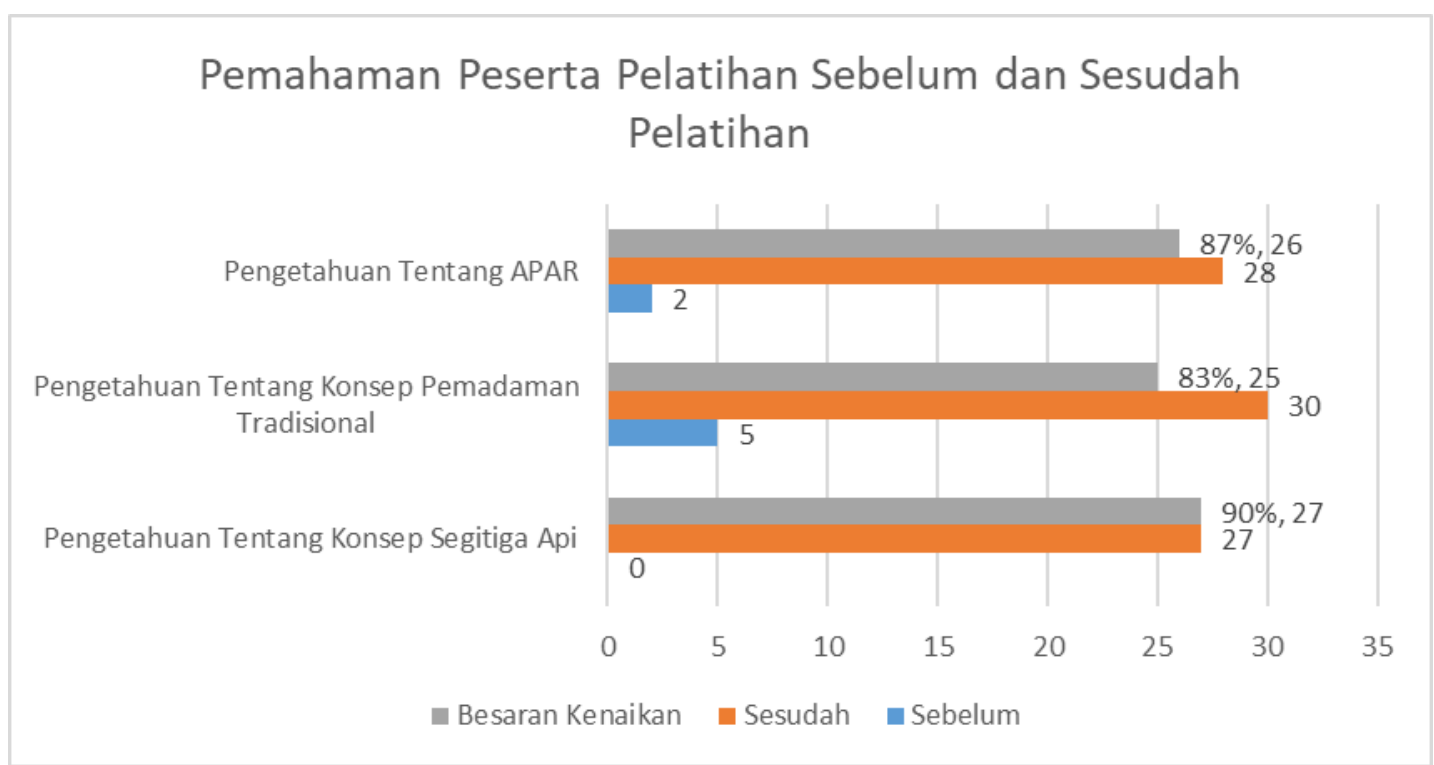

Gambar 2. Grafik Pemahaman Peserta Pelatihan Sebelum dan Sesudah Pelatihan

Dari Gambar 2 menunjukkan bahwa sebelum diadakan pelatihan, peserta pelatihan belum mengetahui konsep dari teori segitiga api, hal ini dikarenakan peserta pelatihan sudah memahami penyebab kebakaran seperti ledakan tabung gas/kompor dan konsleting listrik tetapi belum memahami dasar api dapat terbentuk hingga menyebabkan kebakaran. Sebanyak 5 orang mengetahui pemadaman api secara tradisional dan sebanyak 2 orang mengetahui APAR akan tetapi masih ada yang belum mengerti bagaimana cara menggunakannya. Sesudah dilaksanakan sosialisasi penyampaian bahan pelatihan dengan cara diskusi dan ceramah dan pelatihan penggunaan APAR dan praktik langsung diperoleh peningkatan pemahaman yang cukup signifikan. Peningkatan terbesar diperoleh dari pemahaman mengenai konsep segitiga api yaitu mengalami kenaikan sebesar $90 \%$, peningkatan kedua terkait dengan pemahaman pengetahuan penggunaan APAR yaitu sebesar $87 \%$, dari 2 orang yang paham naik menjadi 28 orang peserta pelatihan, sedangkan untuk pengetahuan tentang konsep pemadaman tradisional mengalami peningkatan sebesar $83 \%$, yang semula 5 orang paham menjadi 25 orang peserta pelatihan yang paham terkait konsep pemadaman tradisional. Berikut ditunjukkan praktik langsung terkait penggunaan APAR dengan peserta pelatihan. 


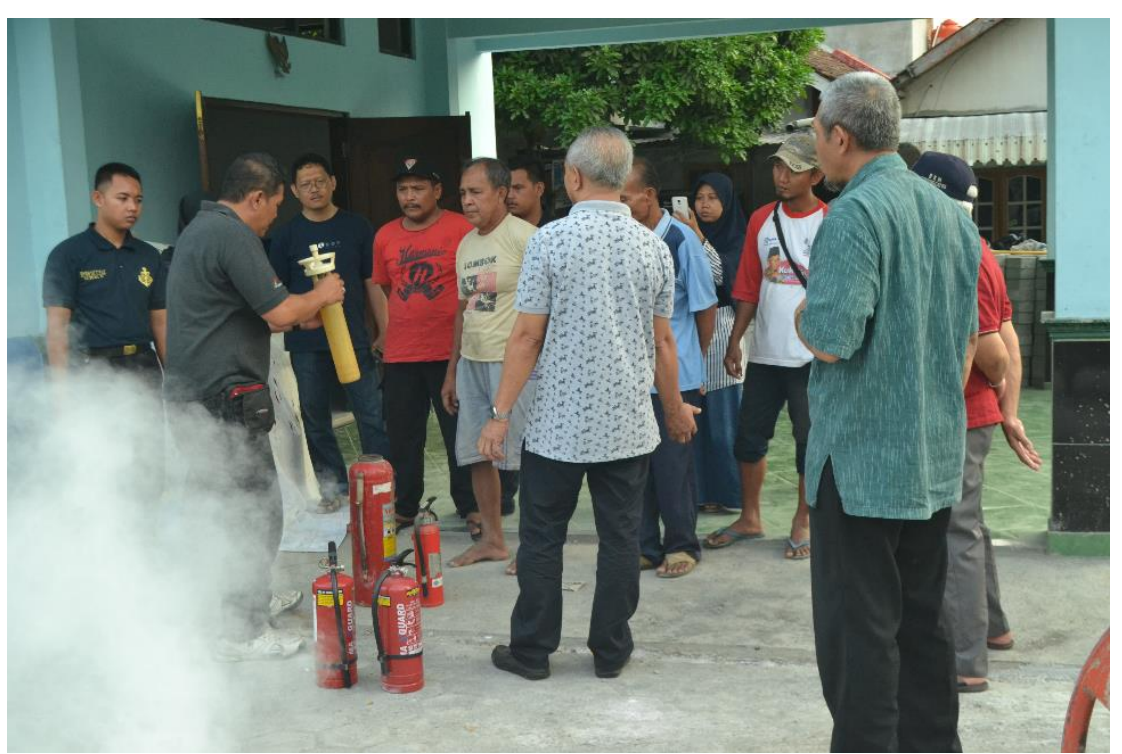

Gambar 3. Proses penjelasan mengenai fungsi dan penggunaan APAR

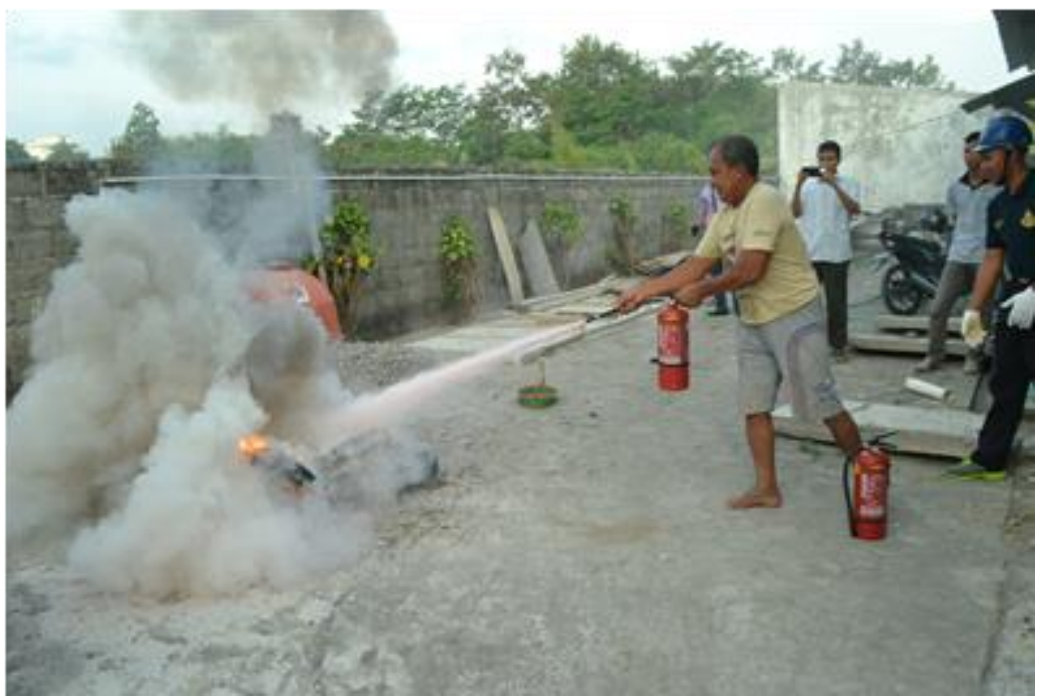

Gambar 4. Peserta pelatihan praktek langsung menggunakan APAR

\section{KESIMPULAN}

Berdasarkan pelatihan perlindungan risiko kebakaran dengan pengenalan dan penggunaan APAR di Condong Catur, Depok, Sleman, Yogyakarta yang dilaksanakan telah sesuai dengan prosedur yang berlaku, mulai dari penyiapan materi, pelaksanaan, dan evaluasi. Dari hasil pelatihan terjadi peningkatan pemahaman sebelum dan sesudah pelatihan, diantaranya terjadi peningkatan pemahaman mengenai konsep segitiga api sebesar 90\%, peningkatan pemahaman pengetahuan penggunaan APAR sebesar 87\%, dan peningkatan konsep pemadaman tradisional mengalami peningkatan sebesar $83 \%$. Adanya pelatihan yang telah dilakukan menjadikan sarana untuk lebih meningkatkan pengertian serta pemahaman peserta pelatihan terhadap terjadinya bencana kebakaran serta bagaimana cara menanganinya. Diharapkan setelah mengikuti materi pelatihan warga masyarakat dapat lebih meningkatkan tentang kesiapsiagaan terhadap bahaya kebakaran. Sehingga pencegahan bahaya kebakaran dapat teratasi serta resiko dan kerugian dari bahaya kebakaran dapat ditekan seminimal mungkin.

\section{DAFTAR PUSTAKA}

Badan Pusat Statistik (2017) Statistik Daerah: Daerah Istimewa Yogyakarta 2017, Badan Pusat Statistik Daerah Istimewa Yogyakarta.

Ghifary, A. (2014) 'Efektivitas Penggunaan Media Iklan Baliho Dalam Mensosialisasikan Bhaya 
Kebakaran Dikota Samarinda', e-Journal Ilmu Komunikasi.

Heide, E. A. Der (2004) Common Misconceptions about disasters: Panic, the "Disaster Syndrome," and Looting, The First 72 Hours: A Community Approach to Disaster Preparedness.

Kurniawan, B., Ekawati, E. and Firdani, L. (2014) 'ANALISIS PENERAPAN ALAT PEMADAM API RINGAN (APAR) DI PT. X PEKALONGAN', Jurnal Kesehatan Masyarakat (eJournal).

Ma'ruf, M. (2010) 'Pedoman Umum Mitigasi Bencana', Pedoman Umum Mitigasi Bencana.

Sardiyo (2010) Pengaruh kondisi wilayah kota terhadap frekuensi kebakaran (studi kasus pada 6 Kelurahan di Kecamatan Tambora Jakarta barat, Planologi. 